\title{
Lesion Number
}

National Cancer Institute

\section{Source}

National Cancer Institute. Lesion Number. NCI Thesaurus. Code C93587.

The integer assigned to a localized pathological or traumatic structural change, damage, deformity, or discontinuity of tissue, org an or body part. 